BIO-CONS, Jurnal Biologi \& Konservasi

Volume 3 No. 2, Desember 2021

p-ISSN : 2620-3510, e-ISSN: 2620-3529

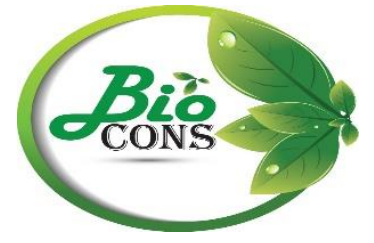

\title{
THE EFFECT OF FERMENTED SHALLOT SKIN ON THE GROWTH OF MUSCLE PLANTS (Brassica juncea)
}

\author{
Waris*, Hasni Ummul Hasanah, Raudhatul Hasanah \\ *) Corresponding Author \\ PGRI Argopuro University, Jember \\ J1. Jawa Nomor 10 Sumbersari-Jember, Indonesia \\ *Email: drwaris668@gmail.com
}

\begin{abstract}
Shallot skin is a kitchen waste that contains good nutrients for plant growth. Shallot skin contains calcium, phosphorus, and iron. The fermented shallot skin has nutrients N-total $1.29 \%$, Corganic $17.32 \%$, P2O5-total $0.46 \%$, K2O-total $0.70 \%$, and so on. This study aims to determine the effect of shallot skin fermentation on the growth of mustard (Brassica juncea) plants. This research was conducted using a Randomized Block Design method consisting of 6 treatments and 4 replications, including; P0 (without fertilizer as negative control), P1 (inorganic fertilizer as positive control), P2 (25 gr), P3 (50 gr), P4 (75 gr), and P5 (100 gr). The observed growth parameters include; plant height, number of leaves, wet weight, and leaf area of mustard plants. The data obtained were analyzed using Anova analysis at a 95\% confidence level, then further tested with Duncan's test. The results of this study showed that the application of organic fertilizer from the fermented shallot skin had a significant effect on the parameters of plant height, number of leaves, and wet weight, but had no significant effect on leaf area of mustard plants. Treatment of organic fertilizer from shallot skin at a dose of 25 grams can replace the application of inorganic fertilizer (urea) on all parameters, except for leaf area.
\end{abstract}

Keywords : Fermentation, Shallot Skin. 


\section{PENDAHULUAN}

Vegetables are a general term for foodstuffs derived from plants. It usually has a very high water content, and is consumed when it is fresh or after being treated to a minimum. Parts of plants that can be eaten and made into vegetables are leaves, stems, flowers and young fruit, so it can be said that all parts of the plant can be used as vegetables (Agroteknologi, 2017).

Rofiatin (2010) said that vegetables are an important commodity in Indonesian dishes, because they are needed in daily life and demand tends to increase. FAO recommends to meet the health needs of vegetable consumption per capita of $75 \mathrm{~kg} /$ year per person. The level of availability of the Indonesian people is also still relatively low, namely $40 \mathrm{~kg} /$ person per year, so with a population of 230 million people, 17.3 million tons of vegetables are needed every year.

Mustard plant is one type of leaf vegetable consumed by the people of Indonesia. Mustard consists of 2 kinds, namely white mustard and green mustard. Mustard has the potential for the needs of the body because of its very high nutritional value, in addition to its very high nutritional value, mustard is believed to be able to relieve itchy throat in cough sufferers (Nurshanti, 2010).

Cultivation of mustard plants includes the selection of certified seeds, planting/nursery, maintenance and good soil management. Soil that can be used to plant mustard greens is soil that has sufficient nutrients for the growth of mustard plants, so that mustard greens can grow and reproduce optimally. Soil that lacks nutrients can be improved through the fertilization process.

Regeista et al (2013) said that, fertilizer is a material used to change the physical, chemical or biological properties of soil so that it becomes better for plant growth. There are two types of fertilizers, namely inorganic fertilizers and organic fertilizers. Inorganic fertilizers are fertilizers that come from factories made with a mixture of chemicals that contain high levels of nutrients, while organic fertilizers are fertilizers that come from manure or from industrial waste while organic fertilizers are fertilizers that come from plants or animals that go through a process of decay by decomposer bacteria.

The current use of organic fertilizers continues to increase along with the awareness of farmers to maintain soil health and reduce expenses along with the high cost of inorganic fertilizers. Organic fertilizers that are widely used are from animal waste and household waste. One example of household waste that can be used as organic fertilizer is shallot skin. 
Shallot skin is a kitchen waste that has sufficient nutrient content for plant growth. Nutrients needed by plants contained in shallots, among others; (1). Calcium (Ca) is needed by plants to elongate cells, stimulate the formation of root hairs, help plant growth upwards and neutralize organic acids that are toxic; (2). Magnesium $(\mathrm{Mg})$ which functions to assist the process of phosphate transport in plants, and accelerate the formation of leaves; (3). Sodium (Na) which functions to improve plant growth when showing symptoms of calcium deficiency; (4). Zinc ( $\mathrm{Zn}$ ) which functions to support vegetative growth and the growth of seeds or fruit, as well as to form hormones; (5). Proteins that function as body building substances, and (6). Phosphorus (P) which serves to stimulate root growth and accelerate flowering (Heri, 2011 in Syifandy, 2017).

The content of shallot skin fermented with other organic waste can produce quite high nutrients, namely, N-total 1.29\%, C-organic 17.32\%, P2O5-total 0.46\%, K2O-total $0.70 \%$, and so on (Saamanet et al., 2014 ). Fermentation is a process of producing an organic fertilizer with the help of microbes or the process of converting organic matter into another form that is more useful with the help of microorganisms in a controlled manner. Therefore, the author took the initiative to conduct research on the effect of fermented shallot skin into organic fertilizer on the growth of mustard (Brassica juncea) plants.

\section{METHOD}

\section{Tools and Materials}

The tools used in this research, among others; polybag, gloves, ruler, label paper, bucket and scale. While the materials used in this study include; mustard seeds, soil as a medium, onion peel, EM4, sugar and water.

\section{Research Parameters}

Several parameters in this study, among others; mustard plant height $(\mathrm{cm})$, number of leaves (strands), wet weight (grams), and leaf area $(\mathrm{cm} 2)$.

\section{Data Analysis}

The results of this study were analyzed by the Anova test followed by Duncan's test using the SPSS 16 application program. 


\section{RESULT AND DISCUSSION}

The results of the research data analysis showed that several test parameters (height, number of leaves, and wet weight) showed an ANOVA value of $<0.05$, so it can be concluded that the treatment given had a significant effect. Meanwhile, the leaf area parameter has no significant effect, because the ANOVA value is $>0.05$. Duncan's further test results for all test parameters can be seen in Table 1. as follows:

Table 1. Results of Duncan's Test Analysis of All Test Parameters

\begin{tabular}{lcccc}
\hline Parameters & Height & Leaves Number & Wet Weight & Leaf Area \\
\hline Treatments & & & & \\
\hline Control - & $24.25^{\mathrm{a}}$ & $10.50^{\mathrm{a}}$ & $35.25^{\mathrm{a}}$ & $694.100^{\mathrm{a}}$ \\
Control + & $28.70^{\mathrm{b}}$ & $14.00^{\mathrm{b}}$ & $52.50^{\mathrm{b}}$ & $904.900^{\mathrm{a}}$ \\
25 gr Shallot Skin & $28.52^{\mathrm{b}}$ & $13.25^{\mathrm{b}}$ & $50.50^{\mathrm{b}}$ & $903.950^{\mathrm{a}}$ \\
50 gr Shallot Skin & $25.75^{\mathrm{ab}}$ & $11.00^{\mathrm{a}}$ & $41.25^{\mathrm{ab}}$ & $799.600^{\mathrm{a}}$ \\
75 gr Shallot Skin & $26.70^{\mathrm{ab}}$ & $11.75^{\mathrm{ab}}$ & $45.50^{\mathrm{ab}}$ & $812.050^{\mathrm{a}}$ \\
100 gr Shallot Skin & $27.00^{\mathrm{ab}}$ & $12.00^{\mathrm{ab}}$ & $46.00^{\mathrm{ab}}$ & $850.225^{\mathrm{a}}$ \\
\hline
\end{tabular}

Note: The numbers that are not followed by the same letter indicate that there is a significant difference in Duncan's follow-up test at an error level of $5 \%$.

\section{Mustard Plant Height Growth}

Measurement of the height of the mustard plant started 15 days after sowing until the plant was 40 days old. The height growth of the mustard (Brassica juncea L) plant which was measured every 10 days during the study is presented in Figure 1. below.

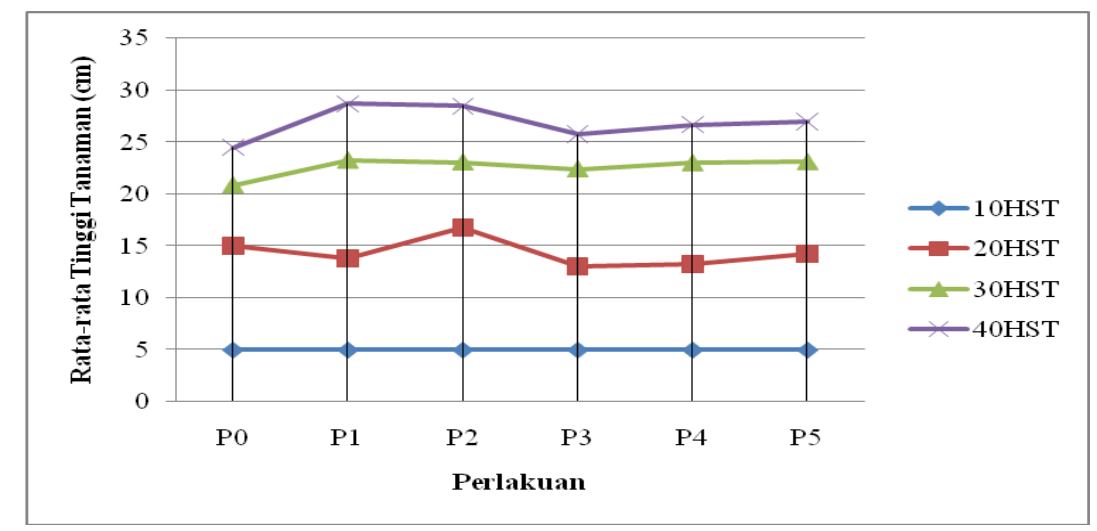

Figure 1. Graph of Average Height Mustard Plant 
Graph above shows the effect of fermented shallot skin on the growth of mustard plant height. This is indicated by an increase in the height of the mustard plant. In all treatments, it was shown that the highest growth in mustard plants was in treatment P1 using inorganic fertilizers. However, even though the highest yield was in treatment P1, treatment P2 with a dose of 25 grams of shallot skin obtained results that were not significantly different from treatment P1, so that its application could replace inorganic fertilizers (positive control).

Sarido and Junia (2017) stated that if the nutrients provided were in accordance with their needs, it would help the growth and development of plants properly. Based on this opinion, it can be said that the nutrients possessed by mustard plants treated with P1 (inorganic fertilizer) and P2 (25gr of onion skin) were available enough, so that they had a good influence on plant growth and development. While the P0 treatment had fewer nutrients than the P1, P2, P3, P4 and P5 treatments so that growth and development were less than optimal.

Heri in Syifandy (2017) said that the high nutrient content of Calcium (Ca) in the skin of the onion is one of the factors that increase the height of mustard plants. Calcium also functions to lengthen cells, stimulates the formation of root hairs, helps plant growth upwards and neutralizes toxic organic acids.

\section{Growth in the Number of Leaves of Mustard Plants}

The calculation of the number of leaves of the mustard plant starts from the 15-dayold plant after sowing to the 40-day-old plant. The calculation of the number of leaves is done by counting the leaves that have been completely opened. The growth of the number of leaves of the mustard plant (Brassica juncea L) which was measured every 10 days during the observations is presented in Figure 2. below. 


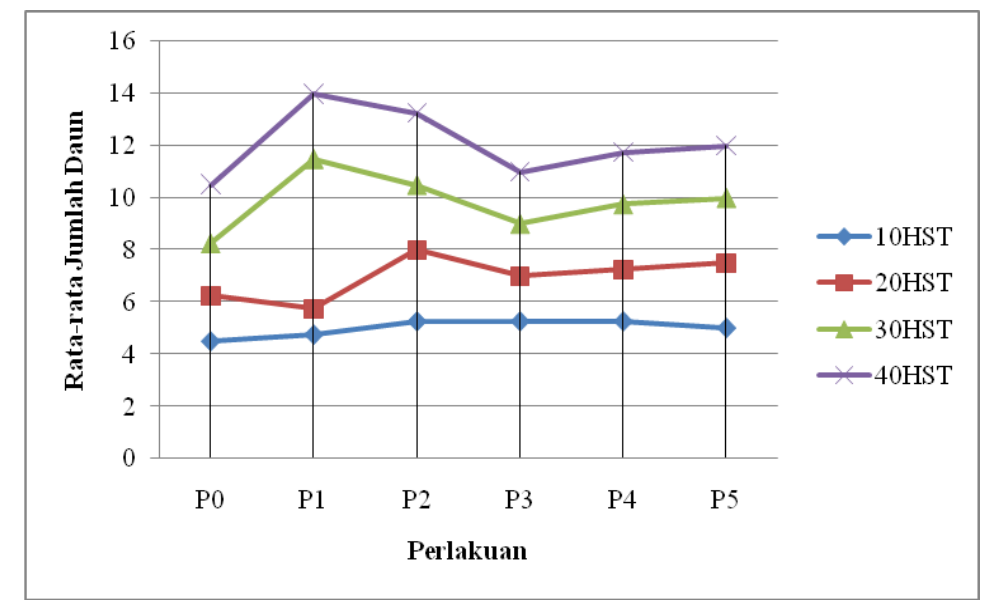

Figure 2. Graph of the Average Number of Leaves of Mustard Plants

Graph above shows that there is an effect of treatment on the number of mustard leaves parameters. This can be seen from the increase in the number of leaves in each treatment, in all treatments leaf growth increased well at 10 HST (days after planting) to 40 HST. The treatment with the highest number of leaves was obtained with inorganic fertilization, but the results were not significantly different from the application of 25 grams of onion peel organic fertilizer. While other treatments showed lower values.

The application of organic fertilizer fermented onion skin of 25 grams was not significantly different from the application of inorganic fertilizer, because both can increase the growth of mustard plants. Although the use of inorganic or chemical fertilizers has a faster growth effect, inorganic fertilizers can damage the physical properties of the soil. Meanwhile, organic fertilizers have a positive effect on the soil and can increase the growth of mustard plants.

In order to accelerate the rate of cell division and elongation as well as the growth of roots, stems, and leaves it is necessary to add sufficient $\mathrm{N}$ elements. So based on this statement, it can be concluded that the P1 (inorganic) and P2 (25gr onion skin) treatments had more $\mathrm{N}$ elements than the other treatments, thereby accelerating the rate of cell division and elongation and resulting in an increase in the number of leaves. Whereas in the P0 treatment (negative control) the nitrogen element was not sufficient for the mustard plant, resulting in a slow rate of cell division and elongation and resulted in a lack of leaf growth.

Sari (2015) stated that the most needed nutrient for plants is nitrogen. Nitrogen functions as a constituent of chlorophyll, protein, fat and other compounds. Chlorophyll available in sufficient quantities will increase the ability of leaves to absorb sunlight energy for the photosynthesis process, with sufficient chlorophyll photosynthesis can run smoothly. 
The results of the photosynthesis process are used for cell division and elongation as well as for plant growth. The resulting cell division and elongation can form new leaves.

\section{Wet Weight Growth of Mustard Plants}

Weighing of the mustard plant was carried out when the mustard plant was harvested using a digital scale. The wet weight of the mustard (Brassica juncea L) plant is presented in Figure 3. below.

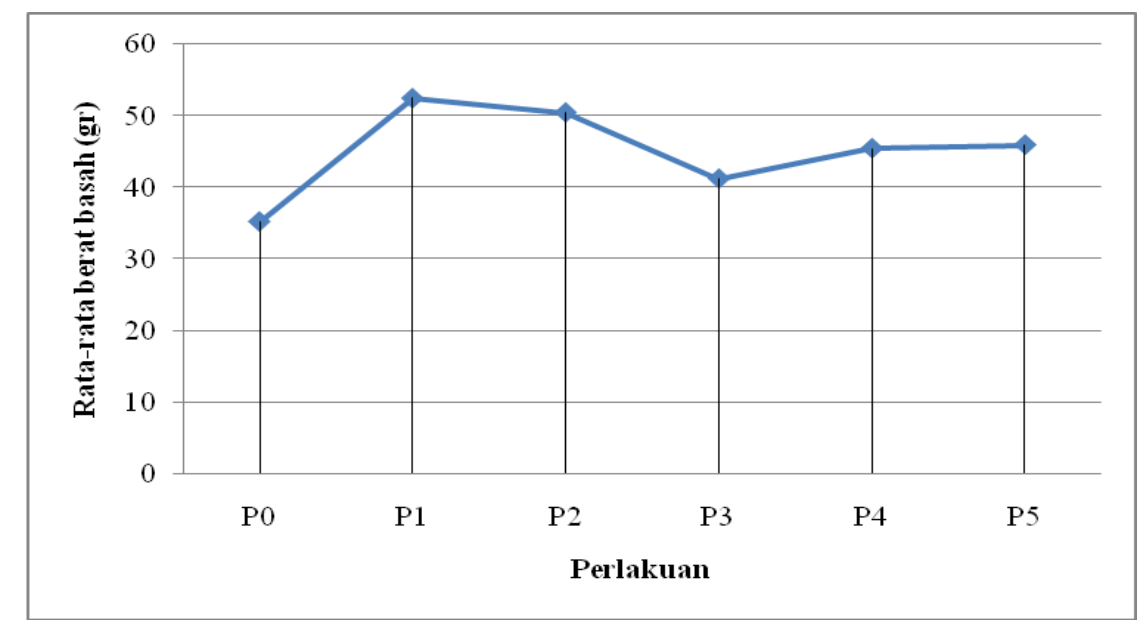

Figure 3. Graph of Average Wet Weight of Mustard Plants

Graph above shows the effect of fermented shallot skin on the wet weight. This is indicated by an increase in the wet weight of the mustard plant. In all treatments, it was shown that the biggest growth in mustard plants was in treatment P1 using inorganic fertilizers. However, even though the biggest yield was in treatment P1, treatment P2 with a dose of 25 grams of shallot skin obtained results that were not significantly different from treatment P1, so that its application could replace inorganic fertilizers (positive control).

Sari (2015) stated that water is the main component in plant life, about 70-90\% of the wet weight of plants is water. Based on this opinion, it can be said that the difference in the wet weight of the mustard plant can be influenced by the ability of the plant to absorb water from the soil. The wet weight of the plant will increase if the plant is able to absorb water optimally. Based on this statement, the wet weight results obtained from this study are thought to be due to the ability of the mustard plant to optimally absorb water from the soil.

In addition to water, wet weight is also influenced by nitrogen content. This is in accordance with Sukmawati's statement in Sarido (2017) which states that the provision of sufficient $\mathrm{N}$ and $\mathrm{P}$ elements can convert carbohydrates produced in the photosynthesis process 
into protein so that it will help increase the number, length and width of leaves so as to produce optimal wet weight.

\section{Leaf Area Growth of Mustard Plants}

The measurement of the leaf area of the mustard plant was carried out when the mustard plant was harvested using the millimeter block method. Leaf area of mustard (Brassica juncea $\mathrm{L}$ ) is presented in Figure 4. below.

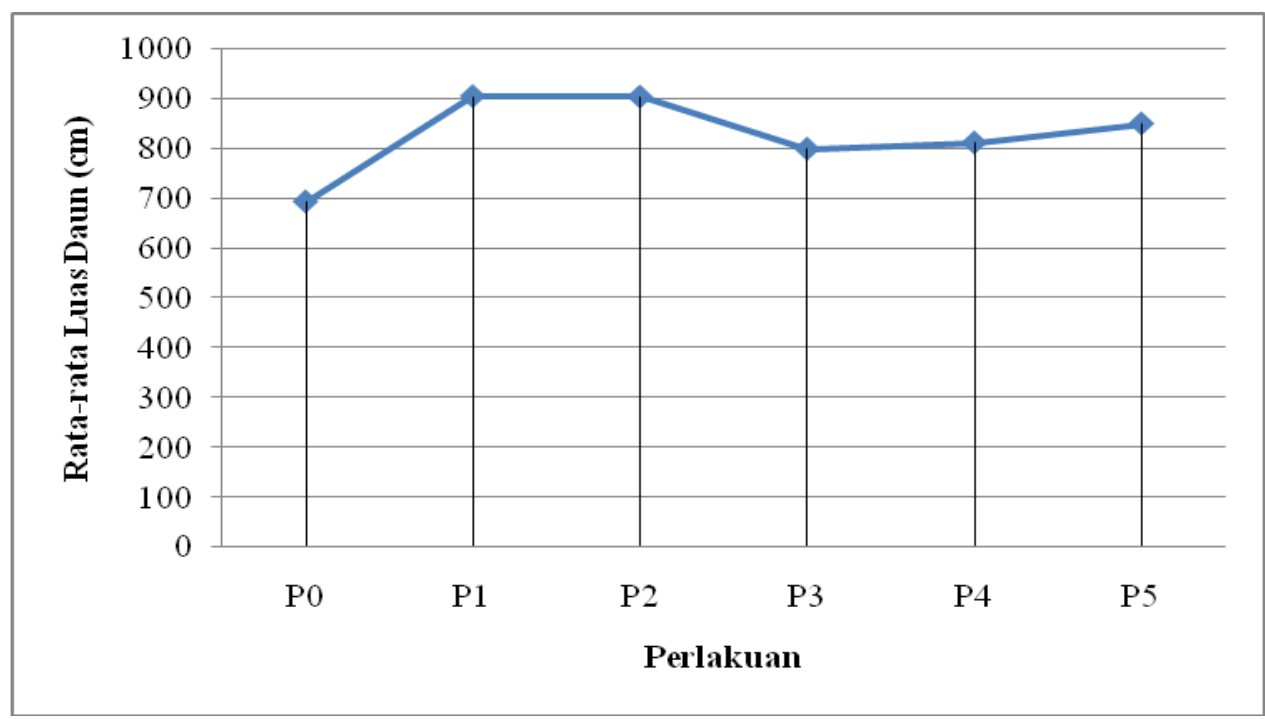

Figure 4. Graph of the Average Leaf Area of Mustard Plants

The results of the anova test showed that the treatment given in this study did not significantly affect all observation parameters, although numerically the inorganic fertilization treatment produced the highest leaf area and was followed by organic fertilizer treatment from onion skin of 25 grams, followed by several other treatments.

These results can occur presumably due to the light intensity factor. The intensity of light affects the leaf area, the lower the light intensity obtained by the plant, the wider the leaves on the plant, while the higher the light intensity obtained by the plant, the thicker the leaves on the plant. This is in line with the research of Afa and Sudarsono (2014) which states that the low growth is caused by the low intensity of sunlight. Providing shade (low light intensity) can reduce leaf thickness on plants, but can increase leaf weight because the leaves tend to be wider.

Leaves are the main component of a plant in the process of photosynthesis. According to Pertamawati (2010), the photosynthetic process will be optimal if the leaves which are the main place for the photosynthesis process take place are more numerous and larger in size. The process of leaf growth becomes longer and wider due to the results of the 
photosynthesis process which is overhauled through the respiration process and produces energy for cell division and enlargement. Based on this opinion, it can be concluded that sufficient nutrients can help the formation of chlorophyll so that the chlorophyll obtained can absorb sunlight energy for the photosynthesis process. The results of the photosynthesis process are used for cell division so that it can produce leaf length and width productivity.

\section{CONCLUSION}

The results of this study showed that the application of organic fertilizer from the fermented shallot skin had a significant effect on the parameters of plant height, number of leaves, and wet weight, but had no significant effect on leaf area of mustard plants. Treatment of organic fertilizer from shaloot skin at a dose of 25 grams can replace the application of inorganic fertilizer (urea) on all parameters, except for leaf area.

\section{REFERENCES}

Afa, L., O. dan Sudarsono, W., A. (2014). Pengaruh Naungan terhadap Pertumbuhan dan Hasil Tanaman Kolesom (Talinum triangule (Jacq.) Willd). Institut Pertanian Bogor. Bogor. Agriplus, 24(2).

Agroteknologi. (2017). Informasi Ilmu Pertanian Indonesia. http://agroteknologi.web.id/perbedaan-sayuran-batang-sayuran-akar-dan-sayuran buah/. Diakses Desember 2021.

Nurshanti, D. F. (2010). Pertumbuhan dan Produksi Tanaman Sawi (Brassica juncea L) Dengan Tiga Varietas Berbeda, Agronobis, 2 (4).

Pertamawati. (2010). Pengaruh Fotosintesis terhadap Pertumbuhan Tanaman Kentang (Solanum tuberosum L.) dalam Lingkungan Fotoautotrof Secara Invitro. Jurnal Sains dan Teknologi Indonesia, 12 (1).

Regeista, F., Halimahtus, S., Alifian, J., dan Mujaroh, K. (2013). Aplikasi Produk Composting Hasil Kombinasi Perlakuan Mikroba Thermotolerant dan Kontrol Suhu Thermophilik terhadap Regrowth Bakteri Patogen di Lahan Pertanian. Prosiding Seminar Nasional Pertanian Organik Yogyakarta. Universitas Gadjah Mada.

Rofiatin, U. (2010).. Efesiensi Usaha Tani Tanaman Sawi. Buana Sains,10 (2), 189-194.

Saaman, R., Chery, S. A., dan Erna, P. A. (2014). Pemanfaatan Limbah Bawang Merah sebagai Sumber Bioenergi Pertanian. Prosiding Seminar Nasional Hari Pangan Sedunia ke-34: Pertanian-Bioindustri Berbasis Pangan Lokal Potensia.

Sarido, L., dan Junia. (2017). Uji Pertumbuhan dan Hasil Tanaman Pakcoy (Brassica rapa L) dengan Pemberian Pupuk Organik Cair pada Sistem Hidroponik. Jurnal AGRIFOR, $16,1$.

Sari, S. Y. (2015). Pengaruh Volume Pupuk Organik Cair Berbahan Dasar Sabut Kelapa (Cocos nucifera) terhadap Pertumbuhan dan Hasil Panen Tanaman Sawi Hijau 
(Brassica juncea L.). Fakultas Keguruan dan Ilmu Pendidikan Universitas Sanata Dharma Yogyakarta.

Syfandi, I. (2017). Pengaruh Ekstrak Kulit Bawang Merah (Alium cepa L) Terhadap Pertumbuhan Tanaman Sawi (Brassica juncea L) Secara Hidroponik Sebagai Penunjang Praktikum Mata Kuliah Fisiologi Tumbuhan. Skripsi. Fakultas Tarbiyah dan Keguruan Universitas Islam Negeri Ar-Raniry Darussalam-Banda Aceh. 